\title{
Integrating Blended Learning in Middle School ELA Classrooms to Support Diverse Learners: Lessons Learned
}

\author{
Joseph John Morgan, University of Nevada, Las Vegas \\ Tracy G. Spies, University of Nevada, Las Vegas
}

\begin{abstract}
The current focus of education is on preparing diverse student populations for college and career readiness. One critical aspect of this preparation is the development of $21^{\text {st }}$ century learning skills that integrate technology to support students in becoming active members of a globalized society. According to the National Assessment of Educational Progress, however, English learners (ELs) and students with disabilities (SWDs) are underprepared to use technology to enhance their learning. Therefore, it is important for schools to find ways to integrate critical technology skills with academic instruction in the education of cognitively and linguistically diverse learners. School leaders are essential to the establishment of this instruction. This paper provides lessons learned from a professional development project focused on training middle school English language arts teachers in the integration of blended learning activities to support these diverse learners. These lessons, with supporting data, are discussed along with implications and recommendations for school leaders focused on providing access to critical $21^{\text {st-century learning skills. }}$
\end{abstract}

Keywords: blended learning, professional development, English learners, students with disabilities, technology

Current educational reform is focused on ensuring college and career readiness for all learners (Morgan et al., 2014; Phillips \& Wong, 2010). One critical aspect of this reform is the development of $21^{\text {st }}$ century learning skills (Barak, 2017; Koh, Chai, \& Lim, 2017; Mishra \& Mehta, 2017), which develop necessary critical thinking for participation in a highly educated, global society (Mishra \& Mehta, 2017) and are a central focus of many policy initiatives (Mishra \& Mehta, 2017; Nelson, Fien, Doabler, \& Clarke, 2016). However, these initiatives often fail to consider $21^{\text {st }}$ century learning for students with disabilities (SWDs) and English learners (ELs) (Darrow, 2016; Pazey, Schalock, Schaller, \& Burkett, 2016), as evidenced by the Technology and Engineering Literacy (TEL) assessment in which $13 \%$ of SWDs and $5 \%$ of ELs scored at or above proficiency (NAEP, 2014). Therefore, it is imperative for school administrators to support teachers in using innovative instructional supports designed to meet the needs of SWDs and ELs to ensure their access to this learning. One such promising practice is the integration of blended learning (Basham, Hall, Carter, \& Stahl, 2016; Bauer-Ramazani, Graney, Marshall, \& Sabieh, 2016; Kazakoff, Macaruso, \& Hook, 2017; Rao \& Torres, 2017).

\section{Blended Learning in School Environments and Pur- pose of Project BELL}

There is confusion regarding the definition of blended learning, as there are a variety of terms used synonymously with blended learning (i.e., flipped classrooms, personalized learning) and different ways to incorporate it in the classroom (e.g., all instruction online, technology as a supplement to instruction; Basham et al., 2016). The key defining factor of blended learning, however, is that students purposefully engage in some component of the curriculum via a digital learning experience (Basham et al., 2016). For the purposes of this paper, blended learning is defined as a mode of instruction in which some of the information is provided via digital or online media, either inside or outside of the traditional classroom, with students having some level of ownership over the time, pace, and place of instruction.

There are several key benefits to using a blended learning approach for diverse learners, including access to immediate formative assessment data to drive instruction (Basham et al., 2016; Bauer-Ramazani et 
al., 2016; Cieminski \& Andrews, 2018; Rao \& Torres, 2017), increased ability to engage in communication and collaboration through project-based learning (Bauer-Ramazani et al., 2016), and ability to differentiate instruction to match individualized cognitive and linguistic learning needs (Kazakoff et al., 2017; Rao \& Torres, 2017). To further explore the use of blended learning for ELs and SWDs, Project BELL (Blended English Language Learning) was designed to teach middle school English language arts teachers working on a campus with a 1-1 computer-to-student ratio to implement blended learning approaches in support of writing outcomes of ELs and SWDs placed in inclusive classrooms. Participating teachers attended eight professional development (PD) sessions across an academic year, including four face-to-face and four online sessions. The topics of these PD sessions focused on writing instruction, blended learning approaches, and evidence-based differentiated practices for SWDs and ELs.

Within these PD sessions, blended learning was defined using the aforementioned operational definition; teachers were tasked with working collaboratively to analyze content standards and their instruction in order to determine spaces where blended approaches could be integrated. This varied based on teacher comfort level and knowledge with blended learning: they could have had the entire lesson occur online and completed at each individual student's pace, or they could have taken a component of the lesson (e.g., introduction to new material, assessment) and converted that to a digital format. The messaging to teachers was that some component of their instruction needed to occur via digital avenues.

A variety of instruments were used throughout Project BELL to better understand how teachers' knowledge regarding the implementation of blended learning - and perceptions of the impact of these activities - on the outcomes of SWDs and ELs changed as a result of the PD activities. To measure changes in knowledge and beliefs, participants completed a 35question survey both before and after the PD implementation. Teachers rated their knowledge and beliefs on a 5 -point Likert scale $(1=$ Strongly disagree and $5=$ Strongly agree). Additionally, teachers were asked to respond to prompts through a blog discussion, submit their lesson plans, analyze characteristics of targeted student writing, and plan instruction based on formative assessment data during the online PD sessions. Data from these tools were triangulated to determine the overall impact of a PD on blended learning on teacher knowledge and beliefs. Descriptive data were analyzed from the surveys and content analysis was conducted on teacher reflections and lesson artifacts.
A total of 14 participants engaged in all aspects of the PD and provided consent to analyze their data (see Table 1 for demographics of participants). While a complete analysis of the impact of Project BELL is beyond the scope of this article, data from these reflections allowed us to learn several critical lessons that could inform school administrators in designing and implementing blended learning approaches on their school sites (Cieminski \& Andrews, 2008; Duffey \& Fox, 2012). These lessons, with supporting data from teacher reflections, are included below with specific recommendations for school administrators (see Table 2 for lessons learned and Table 3 for demographics of quoted participants).

\section{Alignment Between Blended Learning and Standards}

One lesson learned was the need to support teachers in understanding the alignment of blended learning to academic standards. Often, teachers reported implementing blended approaches simply for the sake of the technology and not with a focus on supporting students, particularly those with disabilities and ELs, in mastering targeted objectives. Teacher A designed a lesson using film editing software to create a movie trailer comparing two holidays, with the academic intent of working on comparing and contrasting with evidence. Prior to using the technology to create the trailer, students had to complete a compare and contrast storyboard with evidence. In her reflection, Teacher A commented that some classes "rushed through the storyboard so that they could just work on the trailer. I also found that the students were putting in...pictures...when [they] did not have anything to do with what their paper was about".

In comparison, Teacher B created a blended learning lesson focused on mapping prior to writing. She first taught students how to map through teacher modeling, and then she introduced students to a series of online resources they could use in order to map their writing. Teacher $\mathrm{B}$ reflected on the positive nature of the lesson and how students "liked using the iPad to help them put their paragraph together". She felt the technology worked because "students saw it being modeled and had practiced in small groups" prior to using the technology. These two examples illustrate the importance of having a clear instructional vision for the purpose of the technology to further an academic goal compared to using technology that is engaging for students but not directly aligned to academic outcomes; this is especially true for SWDs and ELS who often require focused instruction aligned to targeted outcomes. Therefore, school 
Table 1

Lessons Learned Regarding Blended Learning PD Focused on Diverse Learners in Middle Grade Classrooms

\begin{tabular}{|c|c|}
\hline Lesson & Considerations for School Leaders \\
\hline \multirow{3}{*}{$\begin{array}{l}\text { 1. Teacher } \\
\text { Alignment } \\
\text { of Blended } \\
\text { Learning } \\
\text { and Stand- } \\
\text { ards }\end{array}$} & $\begin{array}{l}\text { 1.1. Train teachers to unwrap academic content standards; identify instructional objectives } \\
\text { required for mastery. }\end{array}$ \\
\hline & 1.2. Identify objectives that lend themselves to blended learning approaches. \\
\hline & $\begin{array}{l}\text { 1.3. Implement formative assessments; continuously implement assessments to ensure pro- } \\
\text { gress. }\end{array}$ \\
\hline \multirow{4}{*}{$\begin{array}{l}\text { 2. Current } \\
\text { Level of } \\
\text { Teacher } \\
\text { Technology } \\
\text { Integration }\end{array}$} & 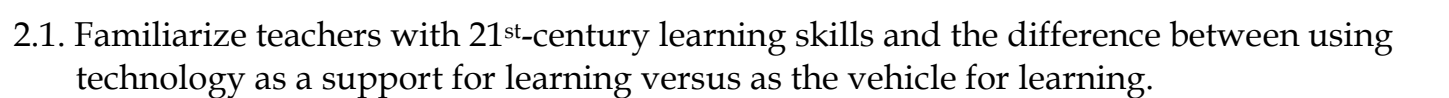 \\
\hline & 2.2. Identify critical $21^{\text {st-century learning skills aligned with academic content standards. }}$ \\
\hline & $\begin{array}{l}\text { 2.3. Design instruction that enhances student voice and choice and encourages the use of } \\
\text { technology to co-construct learning experiences. }\end{array}$ \\
\hline & $\begin{array}{l}\text { 2.4. Observe teacher implementation of technology integration; provide feedback and sup- } \\
\text { port for enhanced integration. }\end{array}$ \\
\hline \multirow{3}{*}{$\begin{array}{l}\text { 3. Evidence } \\
\text {-based Sup- } \\
\text { ports for } \\
\text { ELs and } \\
\text { SWDs }\end{array}$} & 3.1. Use assessment data to understand the cognitive and linguistic needs of ELs and SWDs. \\
\hline & $\begin{array}{l}\text { 3.2. Integrate evidence-based cognitive and linguistic supports in blended learning instruc- } \\
\text { tion. }\end{array}$ \\
\hline & $\begin{array}{l}\text { 3.3. Identify adaptation techniques and strategies necessary to support the academic achieve- } \\
\text { ment of all learners. }\end{array}$ \\
\hline
\end{tabular}

administrators can ensure that PD related to the integration of blended learning allots time focused specifically on supporting practitioners in identifying academic learning outcomes as the primary objective of the technology integration (Morgan et al., 2014; Morgan, Boone, \& Higgins, 2013) and subsequently how the integration of blended learning can: (a) support specific outcomes and (b) provide formative assessment that can be used to determine student growth and mastery (Chang, 2012). Following initial vision setting and PD, it is important for school administrators to provide teachers with collaborative planning time so they can (a) ensure continued alignment to the academic standards and (b) receive support in using the technology for learning (Cieminski \& Andrews, 2018; Duffey \& Fox, 2012).

To achieve this, we recommend PD begin with teachers fully understanding the academic learning outcome that is expected as a result of their instruction. These outcomes can be identified by unwrapping academic content standards to determine the knowledge and skills (Morgan et al., 2014) and language demands (i.e., ways students are expected to use and interact with language; Spies, 2016) associated with mastery of the content. Then, teachers should plan a series of lessons and activities targeting these component academic and linguistic skills with a con- sideration of the needs of SWDs and ELs to ensure alignment of instruction. Finally, teachers can analyze the component learning expectations of the content standard and determine specific instructional components that align themselves well to a blended learning approach (e.g., a software program designed to teach specific academic content standards or components of technology to support or enhance student learning).

Once the academic learning expectations are clarified and instruction has been planned to ensure that students meet targeted expectations, it is important for teachers to collect baseline data from students (Basham et al., 2016; Cieminski \& Andrews, 2018; Morgan et al., 2013). This data should include academic, linguistic, and technology skills (Basham et al., 2016; Chang, 2012). This step is important, as SWDs and ELs who are unfamiliar with the academic skills being targeted through blended learning may not benefit from the technology-enhanced experience if they have not mastered the skill; additionally, students who do not adequately know how to use the technology may also not benefit. Teacher $C$ made this point clear when trying to implement a blended learning experience focused on writing a summary. She reflected, "I assumed that they had written a summary on a topic, a story, or something. Apparently I was wrong...So I implemented a mini lesson on writing a 
Table 2

Demographics of Participants in All Components of Project BELL Activities

\begin{tabular}{|c|c|}
\hline Characteristic & Frequency $(n=14)$ \\
\hline \multicolumn{2}{|l|}{ Gender } \\
\hline Female & 12 \\
\hline Male & 2 \\
\hline \multicolumn{2}{|l|}{ Race/Ethnicity } \\
\hline White/European American & 13 \\
\hline Asian/Asian American & 1 \\
\hline \multicolumn{2}{|l|}{ Grade Levels Taught } \\
\hline 6,7 , and 8 & 4 \\
\hline 6 only & 2 \\
\hline 7 only & 5 \\
\hline 8 only & 2 \\
\hline \multicolumn{2}{|l|}{ Years of Teaching Experience } \\
\hline $0-3$ & 3 \\
\hline $4-6$ & 2 \\
\hline $7-10$ & 2 \\
\hline $11+$ & 6 \\
\hline \multicolumn{2}{|l|}{ Licensure Area } \\
\hline General Education & 12 \\
\hline Special Education & 2 \\
\hline \multicolumn{2}{|l|}{ Preparation Program } \\
\hline Traditional Licensure & 12 \\
\hline Alternative Route to Licensure & 2 \\
\hline \multicolumn{2}{|l|}{ ELL Endorsement? } \\
\hline Yes & 5 \\
\hline No & 7 \\
\hline
\end{tabular}

Table 3

Demographics of Quoted Project BELL Participants in Order of Quotation Throughout Manuscript

\begin{tabular}{lcccccc}
\hline $\begin{array}{c}\text { Quoted } \\
\text { Participant }\end{array}$ & Gender & $\begin{array}{c}\text { Race/ } \\
\text { Ethnicity }\end{array}$ & $\begin{array}{c}\text { Grade Levels } \\
\text { Taught }\end{array}$ & $\begin{array}{c}\text { Years of } \\
\text { Teaching } \\
\text { Experience }\end{array}$ & Licensure Area & ELL? \\
\hline Teacher A & Female & White & 6 & 13 & K-8 & No \\
Teacher B & Female & White & 7 & 2.5 & K-8 & No \\
Teacher C & Female & White & 6 & 18 & Reading & No \\
Teacher D & Male & White & 7 & 2 & $7-12$ ELA & No \\
Teacher E & Female & White & $6,7,8$ & 4 & K-12 Special Ed & No \\
Teacher F & Male & White & 7 & 11 & K-12 Special Ed & Yes \\
Teacher G & Female & White & $6,7,8$ & 15 & K-6, 7-12 ELA & Yes \\
\hline
\end{tabular}


summary, which seemed to ease the fear of writing." Formative assessment data should drive the implementation of the lesson and be tracked during the implementation of blended learning protocols to ensure that students are progressing towards mastery of the intended outcome (Chang, 2012). Again, ongoing collaborative planning can provide teachers a space to reflect on the implementation of blended learning approaches and how instruction might be revised to meet the needs of all students.

\section{Current Levels of Technology Integration}

A second lesson learned through the implementation of Project BELL activities was the need to support teachers in understanding technology integration to enhance student learning and the role of technology in the instructional environment (Holland \& Piper, 2016). To achieve the goal of $21^{\text {st }}$ century learning skills mastery, it is important that teachers are not only using technology as a tool to support traditional teacher-led instructional practices but also teaching students critical thinking and discourse skills needed to problem solve using technology as a central tool (Basham et al., 2016; Bauer-Ramazani et al., 2016; Brenner \& Brill, 2016; Tondeur, Roblin, van Braak, Vooght, \& Prestridge, 2017).

A resource that can be used by school administrators to observe teacher integration of blended learning approaches in the classroom and support them in instructional reflection is the Technology Integration $\mathrm{Ma}$ trix (TIM; Welsh, Harmes, \& Winkelman, 2011). This matrix is designed to determine current levels of technology integration (i.e., entry, adoption, adaptation, infusion, transformation) that support critical student learning objectives required for $21^{\text {st }}$ century learning (i.e., active, collaborative, constructive, authentic, goal -directed; Welsh et al., 2011). In Project BELL, teachers reflected on their lesson's placement on TIM following its implementation. At the beginning of the PD, teachers felt they were actively engaging students in $21^{\text {st }}$ century learning through the integration of technology. After being introduced to TIM, teachers noted that much of their instruction tended to focus on the use of technology in teacher-directed formats. Based on quantitative data, teachers felt they were at the adaptation phase (i.e., third of five advanced phases) of having students actively using technology and at the adoption phase (i.e., second of five advanced phases) in each of the other areas of student learning using $21^{\text {st }}$ century learning skills (i.e., collaborative, constructive, authentic, goal-directed).

While we learned in Project BELL that teachers can actively engage students with technology in the classroom, we also found many of the skills being taught did not reflect advanced integration of $21^{\text {st }}$ century learning; this has implications regarding access for SWDs and ELs to high-level technology integration since these teachers actively worked with that population of students. We reviewed submitted lesson plans and found that technology was often used as a replacement for traditional paper-and-pencil activities (i.e., use of digital graphic organizers, note-taking on an iPad) that would fall on the entry level of TIM. Therefore, it is important for school administrators to determine baseline levels of technology use and student engagement with technology as a learning tool and then provide targeted PD to increase the complexity with which students are using technology in their learning (Brenner \& Brill, 2016; Duffey \& Fox, 2012; Tondeur et al., 2017).

Connected to the first lesson learned, it is important that teachers know the purpose and objective of using the technology. If the focus of instruction is on higher-level critical thinking skills, technology as an aid may not be appropriate. To support $21^{\text {st }}$ century learning skills, it is important that teachers think about how to engage SWDs and ELs in collaboration and discourse using technology through more projectbased learning approaches. There are several sample resources available via the TIM website that provide sample videos and lesson ideas reflective of higher levels of technology integration (https://fcit.usf.edu/ matrix/matrix/). Additionally, school administrators may identify technology leads on their campuses to serve as instructional coaches. These resources can support teachers in understanding the continuum of technology integration as well as how to use technology in the teaching and learning process.

\section{Building in Supports for Diverse Learners when Using Blended Learning Approaches}

The final lesson learned through the implementation of Project BELL was the need to provide explicit support to teachers relative to differentiating instruction to support SWDs and ELs. Blended learning approaches have a promising impact on the academic outcomes of both student populations (Darrow, 2016; Kazakoff et al.,2017; Pazey et al., 2016) as long as the chosen techniques are aligned to their individualized needs (Duffey \& Fox, 2012). On a survey of beliefs about blended learning and technology-enhanced instruction, teacher participants in Project BELL echoed these research findings. When asked if they believed technology could support the linguistic needs of ELs and differentiated instructional needs of SWDs, teachers agreed in a post-survey $(M=4.45 / 5.00$ for both questions). Throughout their reflections, teachers monitored the engagement of two ELs and one 
student with a disability during the implementation of blended learning instruction. Teacher reflections again indicated a belief that blended learning had a positive impact on diverse learner achievement. Teacher D reflected, "two of the three students I'm tracking were able to complete the activity in conjunction with their groups...The use of technology in a group setting to enhance understanding of concepts seems beneficial..." After asking students to use a blended approach to write a story, Teacher E reflected, "What a difference there was between the handwritten and the typed! Sure, their writing was still far from perfect, but not only was it legible, most of the spelling and grammar mistakes were able to be mended enough to make the writing comprehensible."

Even with the promise of technology as a tool for differentiating and supporting instruction, participants indicated some barriers when trying to use technology to support diverse learners. Teacher F indicated the technology seemed to work well during a lesson on comparing and contrasting types of writing, but he reflected,

Where things broke down, however, was in the writing portion of the lesson...the grammatical pragmatics of their writing overtook my intended purpose once they began stringing the words together. Even though all of my students were able to demonstrate their understanding of the difference between formal and casual styles, their writing reverted back to what I can only describe as writing to survive.

\section{Teacher $G$ reflected that one of her ELs}

had the hardest time with [a blended learning webbing activity] due to the fact that she wanted to see what others were doing and duplicate, but not having the same language ability in L2, missed...words in the...organizer and consequently her paragraph had sketchy information and poor sentence structure.

While blended learning has great potential to support diverse students, it is important to provide teachers instruction in evidence-based practices that can be linked to blended activities. For example, teachers may provide additional supports and scaffolds for ELs (i.e., word banks, labeled diagrams, sentence frames, graphic organizers, use of students' native language). For SWDs, teachers may pre-teach using direct and explicit instruction, implement a peer assisted learning strategy (PALS) during blended learning, or pull small groups of students to provide additional intervention and support. Aligned to the first two lessons, it is essential that teachers provide differentiated scaf- folds and supports that are anchored in grade level expectation, supportive of students' developing English proficiency, and aligned to 21st-century teaching and learning to ensure access for diverse students in the classroom environment (Rao \& Torres, 2017). Finding ways to support the integration of both evidence-based supports and strategies and blended learning is critical for increasing the actualization of complex technology use with students from cognitively and linguistically diverse backgrounds.

\section{Implications}

Chang, Chin, and Hsu (2008) found that teachers' integration of technology approaches in their classrooms is highly correlated with the technology leadership provided by principals. With this in mind, it is essential that school administrators set a shared vision with teachers that student mastery of both academic standards and $21^{\text {st }}$ century learning skills be at the center of instructional decision making (Cieminski \& Andrews, 2008). Figure 1 provides a conceptualization of how blended learning could be used to support the academic learning outcomes of SWDs and ELs as a starting point for strategic vision setting on a school campus. Once an innovative shared vision is established, it is critical that school administrators ensure that there is a technological infrastructure on campus that will support teachers in achieving this vision (Duffey \& Fox, 2012). To design a vision using evidence-based practices for ELs and SWDs, as well as secure potential funding for infrastructure expansion, school administrators are encouraged to develop researchpractitioner relationships with university faculty (Brown \& Jacobsen, 2016).

Following the development of a shared vision, it is important that school administrators establish PD plans focused on vision implementation. Often, PD related to blended learning focuses on an isolated piece of technology. These "one shot" PD formats limit teacher opportunities to reflect and build upon learned skill. In addition, they tend to lack a focus on the learning and expectations of diverse classroom environments, including how the technology may be used to enhance the voice, self-regulation, and academic outcomes of cognitively and linguistically diverse learners (Brenner \& Brill, 2016; Tondeur et al., 2017). Therefore, blended learning PD should be ongoing and focus on the individualized needs of teachers using the technology (Cieminski \& Andrews, 2018; Chang, Chi, \& Hsu, 2008; Duffey \& Fox, 2012) and should integrate practices of reflective PD (Spies, Lyons, Huerta, Garza, \& Reding, 2017) across collaborative groups of educators to ensure that content knowledge, technology pedagogy, and EL/special 
Figure 1

Conceptualization of the Intersections of Lessons Learned with Implications for PD Related to the Use of Blended Learning for Diverse Learners

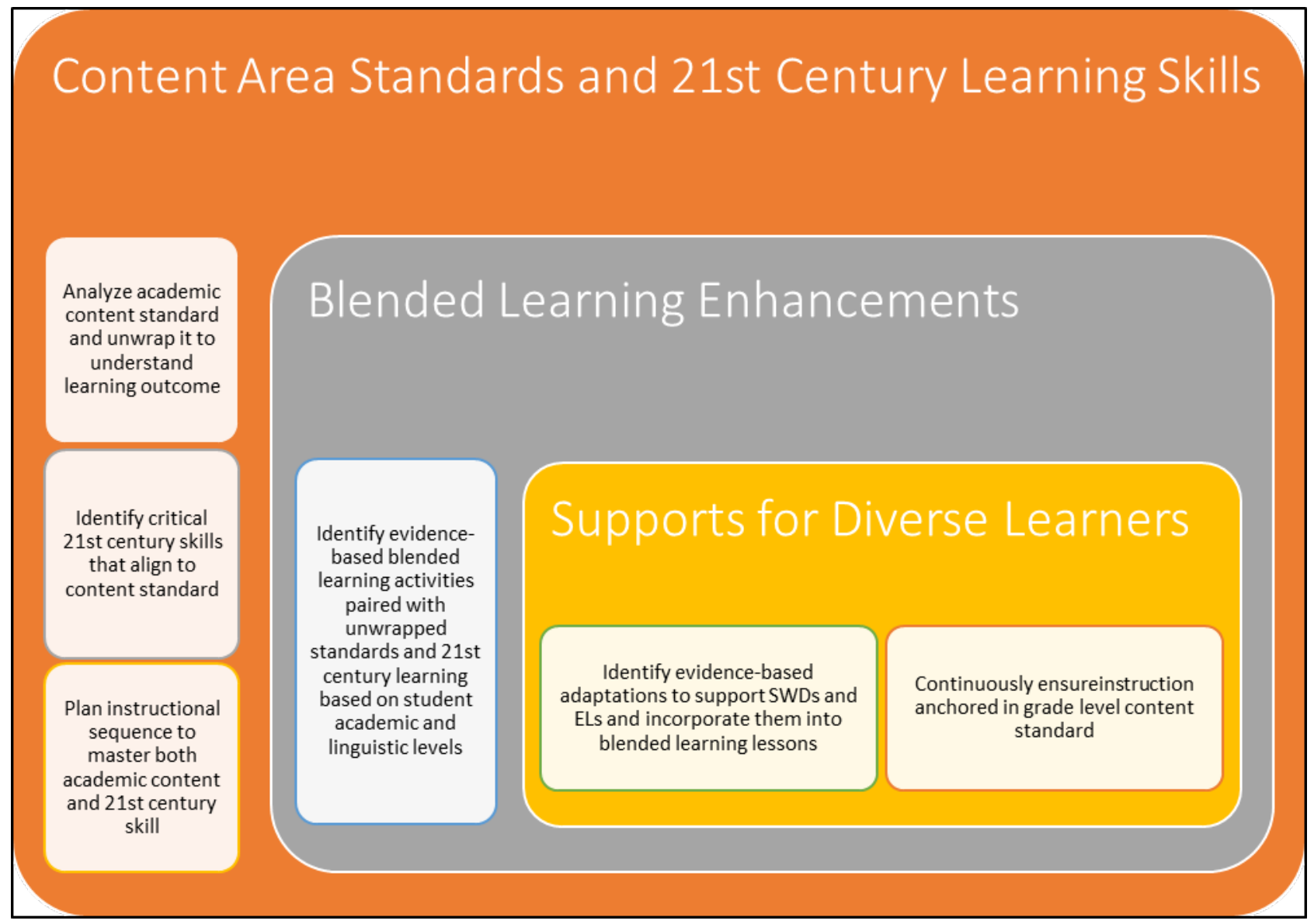

education pedagogy is considered (Morgan et al., 2014). Teachers need to be in an environment where they have the support to take risks and engage in innovative instructional practices (Cieminski \& Andrews, 2018), while also making data-informed decisions related to the learning of diverse learners in the classroom (Chang, 2012; Chang et al., 2008).

The overarching lesson we learned was clear: it is essential that researchers and school administrators find effective methods to integrate technology and develop critical 21 $1^{\text {st }}$ century learning skills for ELs and SWDs, as skills related to complex problem solving and global communication and collaboration are essential for postsecondary success in all areas (Mishra \& Mehta, 2017). English learners and SWDs often lack access to education and instruction in these critical skills, and it is important that school administrators find ways to best prepare teachers to integrate technology in a differentiated and multi-faceted way. Leadership's role is essential in establishing vision and practice that provides access for all students.

\section{References}

Barak, M. (2017). Science teacher education in the twenty-first century: A pedagogical framework for technology-integrated social constructivism. Research in Science Education, 47, 283-303.

Basham, J. D., Hall, T. E., Carter, R. A., \& Stahl, W. M. (2016). An operationalized understanding of personalized learning. Journal of Special Education Technology, 31, 126-136.

Bauer-Ramazani, C., Graney, J. M., Marshall, H. W., \& Sabieh, C. (2016). Flipped learning in TESOL: Definitions, approaches, and implementation. TESOL Journal, 7, 429-437.

Brenner, A. M., \& Brill, J. M. (2016). Investigating practices in teacher education that promote and inhibit technology integration transfer in early career teachers. Tech Trends: Linking Research and Practice to Improve Learning, 60, 136-144. 
Brown, B., \& Jacobsen, M. (2016). Principal's technology leadership. Journal of School Leadership, 26, 811836.

Chang, I. H. (2012). The effect of principals' technological leadership on teachers' technological literacy and teaching effectiveness in Taiwanese elementary schools. Educational Technology \& Society, 15, 328-340.

Chang, I. H., Chin, J. M., \& Hsu, C. M., (2008). Teachers' perceptions of the dimensions and implementation of technology leadership of principals in Taiwanese elementary schools. Educational Technology \& Society, 11, 229-245.

Cieminski, A., \& Andrews, D. (2018). The perfect mix with blended learning, learners choose time, place, path, and pace. The Learning Professional, 39, 50-55.

Darrow, A. A. (2016). The Every Student Succeeds Act (ESSA): What it means for students with disabilities and music educators. General Music Today, 30, 41-44.

Duffey, D., \& Fox, C. (2012). National educational technology trends 2012: State leadership empowers educators, transforms teaching and learning. Washington, DC: State Educational Technology Directors Association (SETDA).

Holland, D. D., \& Piper, R. T. (2016). Testing a technology integration education model for millennial preservice teachers: Exploring the moderating relationships of goals, feedback, task value, and self-regulation among motivation and technological, pedagogical, and content knowledge competencies. Journal of Educational Computing Research, 54, 196-224.

Kazakoff, E. R., Macaruso, P., \& Hook, P. (2017). Efficacy of a blended learning approach to elementary school reading instruction for students who are English learners. Educational Technology Research and Development, 66(2), 1-21.

Koh, J. H., Chai, C. S., Lim, W. Y. (2017). Teacher professional development for TPACK-21CL: Effects on teacher ICT integration and student outcomes. Journal of Educational Computing Research, 55(2), 172-196.

Mishra, P., \& Mehta, R. (2017). What we educators get wrong about 21st-century learning: Results of a survey. Journal of Digital Learning in Teacher Education, 33, 6-19.

Morgan, J. J., Boone, R., \& Higgins, K. (2013). Integrating technology in content area classrooms to support reading comprehension. In R. T. Boon \& V. G. Spencer (Eds.), Adolescent Literacy: Strategies for Content Comprehension in Inclusive Classrooms (pp, 157-169). Baltimore, MD: Brookes Publishing.
Morgan, J. J., Brown, N. B., Hsiao, Y. J., Howerter, C., Juniel, P., Sedano, L., \& Castillo, W. L. (2014). Unwrapping academic standards to increase the achievement of students with disabilities. Intervention in School and Clinic, 49, 131-141.

National Assessment of Educational Progress (NAEP, 2014). The nation's report card 2014: Technology and engineering literacy. https:// www.nationsreportcard.gov/tel_2014/\#.

Nelson, N. J., Fien, H., Doabler, C. T., \& Clarke, B. (2016). Considerations for realizing the promise of educational gaming technology. Teaching Exceptional Children, 48, 293-300.

Pazey, B. L., Schalock, R. L., Schaller, J., \& Burkett, J. (2016). Incorporating quality of life concepts into educational reform: Creating real opportunities for students with disabilities in the $21^{\text {st }}$ century. Journal of Disability Policy Studies, 27, 96-105.

Phillips, V., \& Wong, C. (2010). Tying together the Common Core of standards, instruction, and assessments. Phi Delta Kappan, 91, 37-42.

Rao, K., \& Torres, C. (2017). Supporting academic and affective learning processes for English language learners with universal design for learning. TESOL Quarterly, 51, 460-472.

Spies. T.G. (2016). Utilizing discourse in the development of strategic readers in the content areas. Intervention in School and Clinic, 51(3), 137-144.

Spies, T.G., Lyons, C., Huerta, M., Garza, T., \& Reding, C. (2017). Beyond professional development: Factors influencing early childhood educators beliefs and practices working with dual language learners. CATESOL Journal, 29, 23-50.

Tondeur, J., Roblin, N. P., van Braak, J., Voogt, J., \& Prestridge, S. (2017). Preparing beginning teachers for technology integration in education: ready for take-off? Technology, Pedagogy and Education, 26, 157-177.

Welsh, J., Harmes, J. C., \& Winkelman, R. (2011). Florida's technology integration matrix. Principal Leadership, 12(2), 69-71.

\section{Authors}

Joseph John Morgan, Ph.D., is an Associate Professor of Special Education at the University of Nevada, Las Vegas; his research focuses on the provision of academic and social-emotional access to the general education curricula for students with disabilities.

Tracy G. Spies, Ph.D., is an Associate Professor of English Language Learning at the University of Nevada, Las Vegas; her research focuses on second language acquisition, the effects of second language on native language, and teacher professional development to support second language acquisition. 